\title{
Speaker meaning and accountability in interaction
}

\author{
Michael Haugh \\ Griffith University
}

\begin{abstract}
Speaker meaning is generally defined in pragmatics in terms of the speaker's intentions. The received view is that a speaker means something by intending that the hearer recognise what is meant as intended by the speaker, thereby grounding speaker meaning in a presumed cognitive reality. In this paper it is proposed that speaker meaning can also be conceptualised from a social, deontological perspective where the speaker is held accountable to the moral order for what he or she is taken to mean in interaction. Speaker meaning in this sense encompasses moral or ethical concerns such as rights, obligations, responsibilities, permissibility, and thus is a real-world, consequential concept for participants in interaction. One result of this real-world consequentiality is that the degree of accountability for speaker meanings can be observed to be disputed by participants in both institutional and everyday talk. A second consequence is that the degree of accountability for speaker meanings can be modulated through various meaning-actions that either increase or decrease a speaker's level of accountability for particular meanings. The practice of not-saying is argued to be one relatively neglected meaning-action through which speakers may decrease their level of accountability in interaction. It is concluded that work remains to investigate whether a deontic conceptualisation of speaker meaning can be reconciled with the received view.
\end{abstract}

\section{Keywords:}

Meaning, accountability, commitment, intention, deontological, moral order

\section{Introduction}

The notion of speaker meaning has remained a core focus of research in pragmatics since Grice's $(1957,1989)$ seminal work on so-called "non-natural meaning" (meaning $\mathrm{gn}_{\mathrm{n}}$ ) and speaker intention engendered a move to study meaning that goes beyond what is said. This kind of meaning is generally termed speaker meaning, reflecting the now widespread assumption in pragmatics that it arises through the speaker having a specific kind of meaning (or communicative) intention. Grice defined this kind of complex intention in the following way (where ' $A$ ' refers to the speaker and $x$ refers to the utterance):

A meant $\mathrm{nn}_{\mathrm{n}}$ something by $x$ ' is roughly equivalent to 'A uttered $x$ with the intention to produce some effect in an audience by means of the recognition of this intention'. (Grice [1957]1989: 220)

The essential idea is that a speaker means something by intending that the hearer recognise what is meant as intended by the speaker. What is meant is generally that the speaker has a particular belief, thought, desire, attitude, intention and so on. Following Grice, then, speaker meaning is generally understood as the speaker's reflexively intended mental state. In other words, a speaker's belief, thought, desire, attitude, intention and so on, which is intended by the speaker to be recognised by the hearer as intended. Grice himself was, at least initially, cautious about claiming that 
such intentions reflect psychological reality. And indeed many language philosophers continue to treat speaker meaning as an essentially formal, analytical notion rather than necessarily making claims about the psychological reality of those intentions as noted by Jaszczolt (1999; see also Haugh and Jaszczolt, 2012). However, it is more common in research on speaker meaning in pragmatics to assume that the recognition and attribution of speaker intentions underlies communication, thereby grounding speaker meaning (and intentions) in a presumed cognitive reality (e.g. Bara, 2010, 2011; Carston, 2002; Levinson, 2006; Sperber and Wilson, 1995).

There is, however, an alternative, possibly complementary, way in which speaker meaning can be developed. Intention can be understood not as only a theoretical or a cognitive notion, but also as a deontological notion where the focus is on what the speaker is committed to, or taken to be committed to, in interaction (Haugh, 2012; Haugh and Jaszczolt, 2012). A deontic treatment of speaker meaning shifts the focus to moral or ethical concerns such as rights, obligations, responsibilities, permissibility and so on. In other words, a view of speaker meaning as socially consequential in interaction. We can see how a deontological conceptualisation of speaker meaning is closely related to the understandings of participants themselves in the following exchanges from an episode of Everybody Hates Chris. The first excerpt begins when Chris, a semi-fictional younger version of Chris Rock (who provides the voiceover here), has helped Tasha, a girl he likes who lives next door, to get rid of a mouse. She gives him a kiss on the cheek outside to thank him. The kiss is witnessed by an older boy Jerome who goes up to Chris.

(1)

Jerome: $\quad$ Now I know why they can't get nowhere. Little dude from across

Chris: $\quad$ Well, hey, you know.

Voiceover: That's what you said when you didn't wanna lie, but you didn't wanna tell the truth.

Jerome: I underestimated you little dude. I didn't think you had it in you. ("Everybody hates a liar", Everybody Hates Chris, Episode 4, Season 2, 2006)

Chris responds to Jerome's unstated assumption or belief that Chris is going out with Tasha with a fairly formulaic non-committal response, "well, hey, you know". By not saying they are not going out, Chris is allowing Jerome to continue to maintain this belief. This constitutes an interesting case of pragmatic meaning as Chris is believed to be going out by Jerome, and when given the chance to correct this assumption Chris does not, although notably he does not actually endorse it either. The formulaic response "well, you know" seems to imply here that something does not need to be said as it is already mutually known (i.e., it is presumed as part of the common ground). The question, then, is whether Chris can be understood to have intended (in the deontological sense) to mean that he is going out with Tasha.

Chris continues responding in this way to others whenever Tasha is mentioned, until finally he is overheard by Tasha herself.

(2) (A girl comes up to Chris in the local convenience store and gives her phone number to him)

Girl: $\quad$ You know I heard about you and Tasha.

Chris: Hey, well, you know.

((Tasha walks up behind Chris)) 
Doc: $\quad$ Ahem.

Tasha: Hey, well, you know what?

Chris: Hi Tasha.

Tasha: Don't "hi Tasha" me. Hey, well, you know what?

What were you going to say about me Chris?

You have something to say, say it to my face.

(“Everybody hates a liar", Everybody Hates Chris, Episode 4, Season 2, 2006)

Here Chris is held to account for a response that Tasha seems to interpret as suggesting that something has been left unsaid, more specifically, the belief that Chris and Tasha are going out (when in fact they are not). This is evident from her demand that Chris complete the utterance. It is clear here that not only does Tasha hold Chris accountable for this belief as speaker meant, but also that this meaning has real-world consequences for Tasha's feelings and self-image, as well as for their subsequent relationship. Chris's father, Julius, thus tries to explain to Chris how one can be taken to be responsible for meaning something even though one has not actually said it.

(3)

Julius: $\quad$ Chris, if you're leading to believe you did something with that girl that you didn't do, you need to fix it.

Chris: $\quad$ But I never said we did anything.

Julius: Let me teach you how to treat women, son. If you do something, you should never say anything. If you don't do something, and you don't say anything, that means you did something, even if you did nothing. So by not saying anything, you're doing something. And you need to say something to let people know you did nothing. You understand?

Voiceover: No.

Chris: Yeah.

(“Everybody hates a liar", Everybody Hates Chris, Episode 4, Season 2, 2006)

According to Julius, what we are taken to mean, even if we do not say anything, is a moral concern, as it involves both what we should and should not say in particular situations. While Chris attempts to divest himself of responsibility for this particular meaning, Julius explains that he will nevertheless be held accountable for it by others. Yet Chris is nevertheless right in a sense. He certainly cannot be held as committed to the same degree to the belief that he and Tasha are going out as he would be were he to say that. These excerpts illustrate two very important characteristics of speaker meaning. On the one hand, speaker meaning is fundamentally deontological in nature. It inevitably involves issues of the rights and responsibilities of participants. On the other hand, the relative degree of these respective rights, responsibilities and so on can be modulated through the different ways in which talk can be formulated by participants. There is a difference between saying something and not saying something, as these excerpts illustrate, although ultimately all forms of meaningaction involve participants claiming or attributing some degree of accountability, or at least so it will be argued in this paper.

The treatment of speaker meaning as grounded in issues of commitment and responsibility is not a particularly new idea. As Cavell (1958) noted very soon after the publication of Grice's (1957) seminal paper on speaker meaning, "the 'pragmatic implications' of our utterances are meant...And what we mean to say, like what we 
mean to do, is something we are responsible for" (p.197, emphasis added). But it would be fair to say the view that speaker meaning is fundamentally deontic in nature, and thus is socially consequential, is a perspective that has remained largely subsidiary to the received view of speaker meaning in pragmatics as involving recognition of speaker intentions at the utterance level. In this paper, then, the aim is to make a modest contribution towards redressing the relative imbalance between cognitively-grounded and socially-grounded notions of speaker meaning. This should not be taken, however, as an attempt to negate or otherwise the common view of speaker meaning as grounded in the cognitive processes of participants (Haugh, 2012; cf. Wedgwood, 2011), but rather as a move to explore an alternative, possibly complementary, view on speaker meaning.

This paper begins by outlining the moral roots of speaker meaning in Grice's formative work on conversational maxims, and how the notion of commitment has subsequently been psychologised by Relevance theorists, before contrasting this with treatments of speaker meaning by language philosophers that have drawn from a broader, more socially-grounded notion of commitment. This lays the groundwork for the subsequent discussion, in section 3, of speaker meaning as reflexive intentional states for which speakers are held accountable, and the moral order through which this accountability is constituted. It is next argued that there are two key consequences of treating speaker meaning as emerging through a reflexive relationship with the moral order. In section 4, it is suggested that speaker meanings can be and sometimes are discursively disputed because of their real-world consequentiality. In the following section, one of the ways in which the degree of accountability for speaker meanings can be modulated by speakers themselves through the manner in which they formulate their talk is explored. The paper concludes with a brief consideration of the implications of this approach for the theorisation of speaker meaning more generally.

\section{Speaker meaning and commitment}

It has long been noted that speakers commit themselves to certain meanings through not only what they say (Austin, 1962; Searle, 1969), but also what they implicate (Grice, 1967, 1975). By and large, discussions of commitment in the context of speaker meaning have centred on truth, a consequence perhaps of the treatment of meaning in pragmatics as information first and foremost (section 2.1). However, a broader socially-grounded view of commitment has also emerged where the focus goes beyond the veracity of information to encompass other moral concerns as we shall see in section 2.2.

\subsection{Commitment and truth}

In developing a conceptualisation of speaker meaning that takes into account its inherently deontic characteristics the first port of call is in fact Grice's $(1975,1989)$ work on the conversational maxims, in particular, the Quality maxim. Grice claimed that truthfulness is a fundamental expectation underlying communication in proposing the Quality supermaxim and attendant maxims:

Supermaxim: Try to make your contribution one that is true.

(i) Do not say what you believe to be false.

(ii) Do not say that for which you lack adequate evidence.

(Grice [1975]1989: 27) 
In framing such expectations as maxims Grice was alluding to their overtly normative and thus moral character. In other words, his claim was not that trying to make one's contribution one that is true is something that speakers will always try to do, but rather is something they ought to do, or at least might be expected to do on the moral grounds that to do otherwise would undermine participants ability to communicate meaningfully (that is, with a sense of real purpose). Thus, it was argued, departures from such expectations are likely to be taken by participants to trigger further inferential work, leading to implicatures among other things. Notably, Grice ([1975]1989) placed particular importance on the Quality maxim in arguing that the "other maxims come into operation only on the assumption that this maxim of Quality is satisfied" (p.27). On this view, then, expectations of truth underlie all forms of speaker meaning, since according to Grice (1989) "false information is not an inferior kind of information; it is just not information" (p.371). It is important to note, however, that Grice was not necessarily committed to the psychological reality of such expectations in the communicative process, but rather to the view that it is through such expectations speakers are able to make particular speaker meanings available.

While here has been sustained criticism of Grice's assumptions about truth in regards to the comprehension of metaphor, irony and the like (Sperber and Wilson, 2008; Wilson and Sperber, 2006), the fact that participants have such expectations has not itself been disputed. Wilson and Sperber (2002), for instance, claim that "hearers expect to be provided with true information" (p.627), while Sperber et al. (2010) have more recently argued that "to fulfil the addressee's expectations [of true and relevant information], the communicator should do her best to communicate true information" (p.360). Relevance theorists arguably diverge from Grice, however, in explicitly psychologising such expectations as part of the comprehension process, claiming that "since there is an infinite supply of true information which is not worth attending to...[a]ctual expectations are of relevant information, which (because it is information) is also true" (Wilson and Sperber, 2002: 627). In other words, according to Relevance theorists, in ostensive-inferential communication (i.e. that involving the recognition of speaker intentions), speakers are committed to the truth of what they are understood to mean by hearers unless otherwise indicated. Morency, Oswald and de Sassure (2008) have argued that this means that "inferring commitment... is part of the processes by which hearers derive speaker meaning" (p.197), while Sperber et al. (2010) have more recently claimed that understanding speaker meaning involves the addressee's processes of "epistemic vigilance" that lead to the acceptance (or non-acceptance) of information as true and relevant. ${ }^{1}$

However, although such proposals have made an important contribution to our understanding of speaker meaning, they nevertheless undermine, at least in some respects, the inherently moral character of speaker commitment to the truth (or otherwise) of information, a point which was alluded to in Grice's original proposals. As we saw in the example in the introduction, it can matter an awful lot to participants just how committed a speaker is taken to be to the truth of what he (or she) is understood to mean. Such moral concerns are not some kind of tangent to the main

\footnotetext{
${ }^{1}$ They further propose a useful distinction between vigilance towards the source of information and the actual content of it, where the former refers to "where a speaker intends the addressee to accept what she says because she is saying it", while the latter refers to "where she expects him to accept what she says because he recognises it as sound" (Sperber et al., 2010: 367).
} 
job of determining speaker meaning, as we saw in that example, but can lie at the very core of participants' understandings of speaker meanings (cf. Wilson and Sperber, 2002: 626).

Another problem with framing commitment to speaker meanings primarily in terms of truth and utterance processing is that commitment goes beyond simply the issue of the veracity of information (no matter how important that might be thought to be). Consider the following excerpt from Seinfeld, where George, who is close friends with Jerry, has been going out with someone who ends up looking just like Jerry after having a haircut.

(4)

Jerry: $\quad$ You broke up with her just because she cut her hair! How short?

George: $\quad$ Like that. ((looking at Jerry))

Jerry: $\quad$ You mean like... ((points to his hair))

George: $\quad$...That.

Jerry: $\quad$ So she...

George: Yes...

Jerry: And you don't...

George: Nooo...

Jerry; So...

George: $\quad$ Exactly...

Jerry: Hmmmm...

George: We...must never ever speak of this again...

Jerry: No, no......

((long pause as they stare at the walls))

Hey uh...you wanna see a movie?

George: $\quad$ Actually I think I'm gonna take a few days off. ((starts to leave))

Jerry: I think that's for the best.

("The Cartoon", Seinfeld, Episode 13, Season 9, 1998)

In this conversation, both George and Jerry are overtly not saying certain things through trailing-off their utterances, although they evidently understand each other perfectly well. What they are trying to avoid saying here is that George was going out with someone who ended up looking like Jerry, and that George broke up with her because of this, since this could be interpreted as indicative of something out of place in George's relationship with Jerry (given they are both taken to be heterosexual). What is at issue here is not so much the truth of the beliefs that underpin the unsaid speaker meanings here, for instance, George's girlfriend had a haircut like Jerry's, ended up looking like Jerry, or that George felt uncomfortable going out with someone who looked like Jerry, nor their respective degree of commitment to the truth of these beliefs. Instead what is at issue is a social taboo, namely, the idea that a heterosexual man could find a woman who looks like his friend physically attractive because of what that might entail about their friendship. In treating these things as "unspeakable", they imply that they feel uncomfortable even alluding to such matters, and that some kind of line in their relationship has been crossed. Critically, these implications form part of what they are taken to mean, as they formulate their talk in such a way that signals their deep discomfort in committing to such beliefs and thoughts. Speaker meanings thus go beyond commitment to the truth (or not) of information. They also involve broader deontological issues such as social rights, obligations, responsibilities and the like. 


\subsection{Socially-grounded commitment}

At the same time Grice was developing his approach to speaker meaning, an alternative approach grounded in the idea that speaker meaning can be held to arise with respect to desire-independent reasons for action was being developed in the work of Austin (1962), and was subsequently developed in the work on the illocutionary force of speech acts (Searle, 1969, 1979), as well as in Brandom's (1994) notion of "discursive commitment", and Clark's (1996) notion of "joint commitment". While some of these approaches to commitment have also been primarily concerned with the degree to which an individual is held to be committed to the truth conditions of an utterance (Searle 2007: 33-34), they nevertheless frame this as being distinct from the speaker's desires or intentions (although cf. Harnish, 2005). Instead, speaker meaning is broadly conceptualised in these various approaches as encompassing particular social commitments (irrespective of their stance on the role of speaker intentions). In this way, speaker meaning is conceptualised as fundamentally deontic in character.

One recent approach to commitment that explores the deontological aspects of speaker meaning is that of Carassa and Colombetti $(2009,2011)$. Drawing from the work of the philosopher Gilbert (2000), they propose that speaker meanings invoke deontic affordances for the hearer, that is, "the perceived possibility of affecting the network of deontic relationships that bind him or her to the speaker" (Carassa and Colombetti, 2009: 1849). These deontic affordances are taken by hearers to amount to social commitments on the part of speakers, where the latter are defined as:

desire-independent reasons for action that, contrary to other types of desireindependent reasons for action like moral or legal obligations, are intentionally created by subjects. They can be viewed as bundles of deontic relationships, intentionally created by the very subjects that are connected by such relationships. (Carassa and Colombetti, 2009: 1843).

The speaker meaning that arises from an assertion, for instance, involves the speaker making a propositional commitment to the hearer to the extent that $p$ is true (Carassa and Colombetti, 2009: 1848; cf. Bach and Harnish, 1979; Searle, 1969), while a request arises coordinate with a speaker meaning where a speaker proposes to a hearer "to create a joint commitment to the extent that [the hearer] will do a future action for [the speaker]", and so involves a social precommitment. The deontic relationships created through such speaker meanings involve, as Carassa and Colombetti (2009) point out, "directed obligations" and "correlative rights and entitlements" (p.1842). For example, there are potentially negative consequences for the participants' perceptions of their respective epistemic rights and responsibilities if the speaker asserts something that happens to be completely untrue. It is also important to note that on this view such social commitments may constitute reasons or affordances for the participants' understandings of speaker meanings. Uptake by hearers is thus also treated as "a deontic concept, involving a commitment to the fact that a specific communicative act has been performed" (Carassa and Colombetti, 2009: 1849). It is through uptake, for instance, where a hearer responds by agreeing with assertion or

\footnotetext{
${ }^{2}$ While all of these approaches differ considerably in their detail, they all involve to varying degrees a notion of commitment that is socially or normatively grounded. A review of differences in their conceptualisation of commitment, although important, lies beyond the scope of this paper.
} 
accepting the request, that a joint commitment can be reached (Carassa and Colombetti, 2009: 1848). In other words, speaker meanings involve more than just issues of truth, but encompass moral and ethical concerns as well. ${ }^{3}$

The move to a socially-grounded notion of commitment as being inherent to speaker meaning is arguably long overdue. However, in conceptualising speaker meaning as fundamentally deontic in nature, the question arises as to what is the nature of these deontological concerns, and just how is it that speakers are taken to be socially committed to particular meanings. In next section it is suggested that an interactionally-grounded notion of accountability to the moral order, where speakers are taken to be held normatively committed to, or responsible for, the real-world, social consequences of meanings by participants (including not only hearers but speakers themselves), might prove useful in furthering our understanding of the deontic notion of speaker meaning advocated in this paper.

\section{Speaker meaning and the moral order}

The notion of the moral order originated in the work of $18^{\text {th }}$ and $19^{\text {th }}$ century philosophers, such as Jean-Jacques Rousseau, Immanuel Kant and John Locke, on the question of the existence of God. The term itself is related to the sense of order as a "sequence, disposition or arrangement" inherited from Anglo-Norman and Old French ordre, which was taken to refer to the institutions governing a society by at least the $15^{\text {th }}$ century. This developed into the sense of order as "a method according to which things act or events take place", including the "moral...system in which things proceed according to definite, established or constituted laws" (Oxford English Dictionary Online, 2012). The moral order is now generally understood as a "body of unwritten social mores and conventions which serves to maintain social order" (Wiktionary, 2010).

While sociologists initially took a fairly prescriptive or positivist stance on the moral order as something which controls social behaviour, in the work of the ethnomethodologist, Harold Garfinkel (1964, 1967), the moral order was reinterpreted as a set of (inter)subjective background expectancies through which participants interpret linguistic (and non-linguistic) behaviour. Building on this understanding he defined the moral order as:

perceivedly normal courses of action - familiar scenes of everyday affairs, the world of daily life known in common with others and with others taken for granted...For members not only are matters so about familiar scenes, but they are so because it is morally right or wrong that they are so. (Garfinkel, 1967: 35, emphasis added)

Garfinkel thus viewed the "body of unwritten social mores and conventions" that constitutes the moral order to not only be "socially standardised" but also socially standardising" (Garfinkel, 1967: 36). In other words, the moral order is not only constituted in, but is also constitutive of interaction (cf. Haugh, 2009). Garfinkel's approach to moral order represented a significant departure from prior work in that he treated "the 'seen but unnoticed', expected, background features of everyday scenes" (ibid.: 36) from which the moral order is constituted as an object of study itself rather

\footnotetext{
${ }^{3}$ Carassa and Colombetti $(2009,2011)$ go on to make a distinction between speaker meaning and joint meaning, although since both are socially grounded in deontic relationships, this distinction will not be further considered in this paper.
} 
than being something that is simply assumed by the analyst. Importantly, he also argued that we are accountable to the moral order even when there is no perceived violation of it (cf. Heritage, 1984). The question this raises, however, is how might be tease out member understandings of the moral order. Garfinkel started with his infamous "breaching experiments" where one starts with familiar scenes and asks "what can be done to make trouble" (ibid.: 37) as a means of tapping into the "seen but unnoticed" expectations of the moral order. In one study students were asked to report on what happened when they acted as if they were boarders in their own homes, which entailed at that time in American society conducting oneself "in a circumspect and polite fashion", including "avoiding getting personal", using "formal address" and speaking "only when spoken to" (ibid.: 47). Students reported that they were held accountable for such behaviour in various ways, either through being sanctioned for abnormal behaviour by others reacting with "astonishment, bewilderment, shock, anxiety, embarrassment, and anger and with charges...that the student was mean, inconsiderate, selfish, nasty, or impolite", or through efforts on the part of their other family members to "make the strange actions intelligible and to restore the situation to normal appearances" (ibid.: 47). In the following reported exchange, the father holds the son accountable for his response to his father's attempts to offer a plausible account of his son's earlier "abnormal" behaviour.

(5)

Father: $\quad$ Your mother is right. You don't look well and you're not talking sense. You had better get another job that doesn't require such late hours.

Student: I appreciate the consideration but I feel fine and just want a bit of privacy.

Father: $\quad$ I don't want any more of that out of you and if you can't treat your mother decently you'd better move out!

(adapted from Garfinkel, 1967: 48)

Here the son is being held morally accountable (in the sense that his behaviour is treated as highly inappropriate) by the father for the implications of what he is taken to mean here. In other words, that the son is being taken to mean this in this way is regarded as a moral issue as it transgresses some "seen but unnoticed" expectations that underpin their normal course of affairs. Garfinkel claimed participants have expectations more generally such that they believe they are "themselves entitled and [which] entitle others to claim that they know what they are talking about, and that what they are saying is understandable and ought to be understood" (Garfinkel, 1967: 41-42). In being expectations that involve a sense of entitlement they are sanctionable and thus moral properties.

Garfinkel's work on the moral order did not directly address the issue of speaker meaning as understood in pragmatics given it largely preceded it, but the claim that speaker meanings involve social commitments that invoke deontic affordances and powers such as obligations, entitlements and the like (Searle, 2010), arguably rests on an underlying moral order. It is this moral order, in other words, that confers real-world consequentiality on speaker meanings, and so enables speakers to be held socially or morally accountable for particular meanings. However, in linking the moral order to the notion of commitment or accountability underpinning speaker meaning two further key presumptions are necessary. The first is the assumed intentionality (in Brentano's sense) of linguistic acts, and the second is the presumed 
agency of speakers. As I have recently argued, "linguistic acts are held to be directed, to be about something, and we are presumed to be exercising our agency in producing them. This is why we are held accountable for producing them" (Haugh, 2012: 173, original emphasis). Of course just how hearers figure out what speakers are held accountable for remains a separate question. The point being made here is that speakers can be and are held accountable to the moral order for what they are taken to mean.

The notion of accountability which was developed in the work of Garfinkel (1964, 1967) and Sacks ([1964]1992) can be differentiated into two types according to Heritage (1988). On the one hand, participants are normatively accountable for what they are taken to mean, in the sense of "the taken-for-granted level of reasoning through which a running index of action and interaction is created and sustained" (Heritage, 1988: 128). On the other hand, participants can be held or hold themselves morally accountable for what they are taken to mean, in the sense of "overt explanation in which social actors give accounts of what they are doing in terms of reasons, motives or causes" (ibid: 128). In both cases, however, participants draw from the underlying moral order in attributing or claiming accountability for speaker meanings. In other words, the moral order constitutes "an ever-present working assumption of conversational interactants, which underlies the ways in which we normatively "make available" meanings through what we say, and are held committed to or accountable for making such meanings available, even when it might not match our claimed intentions (in the folk, discursive sense)" (Haugh, 2012: 168). It is in this sense, then, that speaker meaning is arguably social and discursive rather than private and idiosyncratic in nature (Sanders, this issue). It also the presumed accountability to the moral order that explains why "the burden of proof is on speakers to show that they could have had any other communicative intention in producing that utterance in that context just then than the one they are accountable for having, and credited with, by the social basis of communicative intentions", as Sanders (this issue: 23-24) goes on to argue.

Building on this discussion of the moral order and accountability we are now in a position to offer an alternative characterisation of a deontological notion of speaker meaning as meaning representations for which speakers are routinely held reflexively accountable. A meaning representation here refers to a reflexive intentional (in the philosophical sense of directed) mental state-process that arises as a consequence of the speaker's linguistic (and non-linguistic) behaviour. Intentional mental state-processes refer not only to intentions/intending, but also beliefs/believing, thoughts/thinking, attitudes/evaluating, feelings and the like, which depend, in turn, on attention/attending, perceptions/perceiving, inferences/inferring, interpretations/interpreting and so on and so forth. Thus a speaker's belief that is believed by the speaker to be recognised by the hearer as believed by the speaker as $a$ consequence of a linguistic act constitutes a meaning representation, for instance, although whether it is treated as a speaker meaning depends on whether or not the speaker is held accountable for it. To be held accountable here refers to participants treating the speaker as socially committed to and/or responsible for the meaning representation(s) in question. This refers not simply to the truth or veracity of its content, but the real-world social or interpersonal consequences of it. The moral order that is constituted through, but also constitutive of speaker meanings involves assumed rights, obligations and so on.

One of the most studied aspects of the moral order in relation to speaker meaning is what Heritage has termed the "epistemic order", essentially what 
participants "know relative to others, what they are entitled to know, and what they are entitled to describe or communicate" (Heritage, 2009: 309). Stivers, Mondada and Steensig (2011) also describe the epistemic domain that forms part of the broader moral order as encompassing "epistemic authority over knowledge and differential rights and responsibilities with respect to knowledge (p.3, emphasis added). Heritage (2012a, 2012b) has recently argued that the epistemic domain is one of the resources through which participants are able to hold each other accountable for particular social actions. However, the argument can be extended to speaker meanings as well. As Sperber et al. (2010) point out "making an assertion typically involves claiming enough epistemic authority to expect epistemic trust from the addressee" (p.366). In other words, hearers (or recipients more broadly) can hold speakers accountable for asserting something, thereby (tacitly) invoking the attendant set of social commitments that asserting entails, with reference to a presumed epistemic order. Heritage (2012b) suggests declaratively formatted utterances that are presumed to be addressed to matters in the recipient's epistemic domain are routinely treated as requests for information, while when addressed to matters in the speaker's epistemic domain they are routinely treated as tellings. Of course under certain conditions such assumptions are defeasible (Sidnell, 2012), but the point here is that it is through reference to the epistemic order that speakers can be held accountable for particular meanings. The moral order is, of course, multi-faceted and multi-layered, and the epistemic domain is just one part of a much larger and richer tapestry.

Having argued that speaker meanings are inherently deontological in that participants draw from the moral order to hold speakers accountable for their realworld social consequences, we can now move to consider the analytical implications of taking such a stance. As De Brabanter and Dendale (2008) point out, one issue that has not received sufficient consideration in studies of speaker meaning is what exactly are speakers held to be committed to when making an assertion, for instance. Given that pragmatic meaning representations, such as implicatures, involve reflexive intentional mental state-process that are made available publicly through communication, they are inevitably indeterminate to some degree (Haugh, forthcoming; cf. Sperber and Wilson, 1995; Wilson and Sperber, 2012). The question then is which of these pragmatic meaning representations (presuppositions, implicatures and the like) can speakers be held accountable for, and to what degree? While the moral order is routinely invoked to address this problem, there are also instances where speaker meanings are disputed by participants because of their realworld consequentiality. In other instances, speakers may attempt to formulate their talk in such a way as to modulate their degree of commitment to meanings, thereby increasing or decreasing their degree of accountability for particular speaker meanings. In the next section, the ways in which accountability for speaker meanings can be disputed by speakers and other participants is discussed. In the section that follows one of the practices through which accountability for speaker meaning can be modulated by speakers is explored.

\section{Disputing accountability}

It is well known that people can argue about what has been meant by a speaker. This is generally treated as an example of miscommunication or misunderstanding of the speaker's intention in pragmatics. However, to label a particular interaction as involving miscommunication or misunderstanding constitutes an evaluation first and foremost (by the analyst or lay observers), and does not necessarily constitute analysis 
per se. This is not to say that diverging interpretations of what is meant by the speaker do not arise. Indeed, diverging interpretations most likely arise much more often than we realise in interaction. This is evident from the existence of normative mechanisms for dealing with troubles in speaking, hearing and understanding across languages, or what is termed "repair" in Conversation Analysis (Schegloff, Jefferson and Sacks, 1977; Schegloff, 1997, 2000). However, in some instances we are dealing with diverging interpretations that are of a different order, namely, the issue of whether hearers - or other recipients more broadly - holding speakers accountable for particular meanings is considered legitimate or warranted by those participants.

Consider the following excerpt from an episode of Seinfeld where two characters are arguing over what is meant by Elaine's question. The conversation begins when Elaine tells Jerry that her colleague (Dick), who is a former alcoholic, picked up Jerry's drink by mistake at a party they recently attended, and has since started drinking again, leading to his dismissal.

(6)

\begin{tabular}{|c|c|}
\hline Elaine: & Dick was fired. \\
\hline Jerry: & $\begin{array}{l}\text { You mean to tell me if I had put that drink six inches } \\
\text { over to the right, none of this would have happened. }\end{array}$ \\
\hline Elaine: & $\begin{array}{l}\text { You knew he was an alcoholic. Why'd you put the } \\
\text { drink down at all? }\end{array}$ \\
\hline Jerry: & What are you saying? \\
\hline Elaine: & I'm not saying anything. \\
\hline Jerry: & You're saying something. \\
\hline Elaine: & What could I be saying? \\
\hline Jerry: & Well you're not saying nothing, you must be saying something. \\
\hline Elaine: & If I was saying something I would have said it. \\
\hline Jerry: & Well why don't you say it? \\
\hline Elaine: & I said it. \\
\hline Jerry: & What did you say? \\
\hline $\begin{array}{l}\text { Elaine: } \\
\text { ("The re }\end{array}$ & $\begin{array}{l}\text { Nothing. (sighs) It's exhausting being with you. } \\
\text { Seinfeld, Season 3, Episode } 12,1991 \text { ) }\end{array}$ \\
\hline
\end{tabular}

Here, Jerry and Elaine are arguing about whether Elaine has implied that it is Jerry's fault that Dick was fired, or whether it was simply meant as an information-seeking question. Elaine treats Jerry's interpretation as a miscontrual of what she meant, arguing that "If I was saying something I would have said it". Jerry, on the other hand, appears to appeal to what would normally be understood by Elaine's question (e.g. "Well you're not saying nothing, you must be saying something") in order to hold her accountable for this implicature. The two characters eventually reach an understanding that they have diverging interpretations of what is meant by Elaine's question, and so leave unresolved the question of whether Elaine is implying something or simply not-saying something here. It is important to note that the former would entail a higher degree of commitment on her part to that unsaid content than the latter.

Lawrence (2003: 196) argues that such cases involve "understandings [that] are rejected not as misunderstandings but as misconstruing the prior turn" of talk, while Haugh (2008) suggests in some cases we are dealing with what Rancière (1999) terms "misunderstanding on a deeper level (French: mésentente)" rather than "simple misunderstanding (French: malentendu, or méconnaissance, i.e. a wrong 
understanding, or even a lack of understanding)" (Mey 2001: 217). Whether one talks of "illegimate or unwarranted understanding" or mésentente what is primarily at issue is the moral implications or real-world consequentiality of the speaker being held accountable for certain meanings by participants. In other words, we can observe in such cases the surfacing of the usually backgrounded "seen but unnoticed" moral order in relation to speaker meanings.

Miscontruals or mésentente can become the subject of high-stakes talk for participants in institutional settings. Here being held accountable for particular speaker meanings can have real-world implications for not only the person in question, but also for others with whom he or she is associated, and even for inter-group relations in society more generally in some cases. A particularly salient example of this arose subsequent to the reporting of a partial (and later full) translation of a sermon given to worshippers at a mosque in Sydney in September 2006 by one of Australia's most senior clerics at that time, Sheikh Taj al-Din al-Hilali (who was also known then as the Grand Mufti of Australia). The passage from his sermon that caused the most controversy is reproduced below:

If you take out uncovered meat and place it outside on the street, or in the garden or in the park, or in the backyard without a cover, and the cats come and eat it... whose fault is it, the cats or the uncovered meat? The uncovered meat is the problem. If she was in her room, in her home, in her hijab, no problem would have occurred. ("Muslim leader blames women for sex attacks," Richard Kerbaj, The Australian, 26 October 2006)

Those who were offended by this passage interpreted what Hilali said as implying that 'women who dress inappropriately invite rape', 'it is the fault of women who dress inappropriately if they are raped', and so 'in these situations the fault for rape cannot be solely attributed to the perpetrators' (Haugh, 2008: 205). As Haugh (2008) went on to show, numerous accounts were offered to either support the above interpretations or to refute them as miscontruals. The moral implications of what Hilali was taken to mean by the passage became particularly salient in an interview with him on the Australian version of 60 Minutes. Here the interviewer, Ray Martin, holds Hilali accountable for the real-world consequences of speaker meanings that had been attributed to him (see Appendix for a list of transcription conventions).

(7) (Ray Martin is questioning Sheikh Hilali in a recorded interview)

1 RM: You are qu:oted (.) in this year? in saying that the holocaust, which we know killed six million Jews, that it- was a <Zionist li:e>. You're $\uparrow$ quoted as saying that. Why would you say that.

$2 \quad \mathrm{H}: \quad$ ((translated)) I would like to stress that I condemned the holocaust. But there are hundreds upon hundreds of others who are saying that the fi:gures are not correct.

3 RM: But you're the gra:nd mufti (.) you're the gra:nd mufti. Why would you sa:y something like that which is going to offend everybody?

$4 \quad \mathrm{H}: \quad$ ((translated)) I say straightaway what is in my heart. I $\uparrow$ sa:y it.

5 RM: I hear what you are saying Sheik Alhilali. But (.) but (0.2) you ca:n't say these things, and then say I was misunderstood, misinterpreted, I meant something else. If you say them they 
exist. If you say these things about rape, about Jews, about

$6 \quad \mathrm{H}: \quad$ ((translated)) My words, as correctly understood, I sta:nd behind.

("Defending the faith : Sheik Taj Aldin Alhilali", 60 Minutes, Channel 9, 12 November 2006)

In this excerpt, we can see how the interviewer frames what Hilali has been reported as saying as having real-world consequences, namely, "if you say them, they exist" and "if you say them, people believe you". In other words, no matter how Hilali might intend what he says to mean (or claim to intend as in turn 6), the interviewer argues that such meanings nevertheless arise ("they exist"), they have real-world consequences ("people believe them"), and Hilali is accountable for them, even more so because he held at that time a recognisable position of authority in the Muslim community in Australia. Not only do we have a case here of two participants disputing what speaker meanings Hilali can be held accountable for, the deontological implications of this dispute are very clear. For the interviewer, who speaks in effect for mainstream Australian society, these are things that should not be said or meant. In other words, Hilali does not have the right or entitlement to say such things. For Hilali, on the other hand, saying such things lies within his rights, as he naturalises them as speaking from the "heart" (turn 4). He also treats the interpretations of what he has meant outlined by the interviewer as miscontruals for which he is not responsible (cf. Haugh, 2008: 213). The main point here is that speaker meaning is quite clearly a real-world socially consequential concept. This becomes most obvious in cases where the presumed moral orders of participants diverge.

However, discursive disputes over miscontruals or mésentente of speaker meanings and thus the degree of accountability for those are also to be found in more everyday, potentially less high-stakes talk (Lawrence, 2003; Walker, Drew and Local, 2011; cf. Sidnell, 2012: 56-59). In the following excerpt from a telephone call between two college students we can see another instance of the hearer's understanding of the speaker's prior meaning being treated as a miscontrual rather than simple misunderstanding.

(8) UTCL ROM8a. 1. 1

\begin{tabular}{|c|c|c|}
\hline 1 & Dee Ann: & What Doin'=h \\
\hline 2 & Skeet: & Wha' I'm doin'? \\
\hline 3 & Dee Ann: & Uh huh \\
\hline 4 & Skeet: & Goin' ta bed \\
\hline 5 & & $(0.2)$ \\
\hline 6 & Dee Ann: & Are you really? \\
\hline 7 & Skeet: & Yep $[\mathrm{h}$ \\
\hline 8 & Dee Ann: & [Why? r'ya sick? \\
\hline 9 & & $(0.2)$ \\
\hline 10 & Skeet: & No I'm jus tired= \\
\hline 11 & Dee Ann: & $=$ Tired \\
\hline 12 & Skeet: & ${ }^{\circ}$ Yeah. ${ }^{\circ}$ \\
\hline 13 & & $(0.4)$ \\
\hline 14 & Skeet: & Went to bed too late las' night.= \\
\hline 15 & Dee Ann: & $=\left({ }^{\circ} Y_{e}{ }^{\circ}\right)$ I donno why: \\
\hline 16 & & (.) \\
\hline
\end{tabular}


Skeet: huh huh [.h N o t ] my fault.

21 Skeet: ((spoken in an exaggerated regional dialect))

\section{2}

Skeet:

[(No idea.)]

(Lawrence, 2003: 197)

The excerpt begins with Dee Ann pursuing an account for why Skeet is going to bed (presumably earlier than usual) (lines 1-12). When Skeet eventually offers an account for his fatigue in line 14, Dee Ann responds with an ironic tease in line 15, where she alludes to it being something she already knows (and that he knows she knows), and thus stating the obvious (Lawrence, 2003: 198). Dee Ann then uses in line 17 "a kind of exaggerated, 'countrified', regional dialect (possibly central Texas) that is compatible with her posture of innocence] to distance herself from the delicate action of treating Skeet's account in Line 14 as shifting blame to her" (ibid: 199). In other words, she displays an understanding of Skeet's prior utterance in line 14 as implying she is to blame for his getting to bed late the night before and thus for his fatigue that day by denying it in line 17 (albeit through a shift in footing). Skeet subsequently rejects Dee Ann's denial that she is to blame, however, and moreover, treats it as highly unexpected through his delayed response in line 21, and the glottal cut-off of "I' and the beat of silence before "didn't" (ibid: 199). In doing so he treats Dee Ann's interpretation of his prior talk in line 14 as implying she is to blame as a miscontrual, as "he denies having authored talk that could be construed as shifting responsibility to Dee Ann... and invokes an entitlement to having the account treated as having the plainfully intelligible character that he attributes to it" (ibid: 200, emphasis added). In other words, Skeet disputes Dee Ann's attribution of this implicature as being speaker meant in line 21 by implicitly rejecting the way in which she holds him accountable for it in line 17, a claim of authorial authority she subsequently acknowledges in line 22. As Lawrence (2003) points out, this shows how "speakers do not merely expect to be understood but insist on an entitlement to the manifestly intelligible character of their talk" (p.203), thereby illustrating the connection between speaker meaning and the moral order, which is realised through participants holding speakers accountable to the moral order for these meanings. Speaker meaning is thus quite clearly treated as socially consequential in everyday settings as well. In the next section, we move to consider how this degree of accountability can be modulated by speakers.

\section{Modulating accountability}

What speakers are taken to mean depends in part on the way in which information is made available (Bach, 2012; Horn, 2012; cf. Saul, 2002), or in CA terms, how talk is formulated by the speaker (Garfinkel and Sacks, [1970]1986; cf. Bilmes, 2009; Deppermann, 2011). Grice, ([1975]1989) initially claimed there is an important distinction to be made between saying and various other kinds of meaning-actions, such as implying, suggesting (to which we might add hinting, insinuating, indicating, alluding, inferring and so on), in proposing a distinction between what is said and the technical notions of implicate/implicature/implicatum (p.24). The latter terms (purposefully) conflated rather than distinguished, however, between these different types of meaning-action. There has subsequently been limited work on possible 
similarities and differences between various meaning-actions (Bertuccelli Papi, 1996; Parret, 1994; Weizman, 1985). This is surprising given that formulating speaker meanings through these various different kinds of meaning-actions is one way in which speakers can modulate their degree of accountability for those meanings. Modulating accountability can be directed at asserting the speaker's entitlement to authorship in cases where it might appear accountability for meanings is diffused across participants, as is the case for co-constructions (Haugh, 2010), for instance, or at decreasing the speaker's relative accountability for meanings. It is to a practice for achieving the latter, namely, not-saying, that we will now turn.

Not-saying encompasses instances where the speaker leaves the interpretation of what has been said or implied open to the recipient, although within a certain constrained scope (Haugh, 2011; see also Clark, 1997; Jaszczolt, 1999: 85). In the following excerpt, George is talking about his afternoon walk with the cashier and whether it counted as a date or not.

(9)

Jerry: What exactly did you say when you asked her out?

George: I said, "Would you like to go for a walk or something?"

Jerry: Oh, a walk, well...

George: Or something. I said, "Or something"!

Jerry: Or something. Yeah, that's a date.

("The Soup", Seinfeld, Episode 7, Season 6, 1994)

Here George responds to Jerry's question about how he asked the woman out by reporting on the exact formulation of his talk. It is clear that George interpreted his utterance to the woman, "Would you like to go for a walk or something?", as meaning something beyond what is said, namely, that George is issuing an invitation for a date, rather than simply getting to know the woman in question. However, despite George arguing for this particular interpretation, and Jerry subsequently endorsing it, it remains debatable whether George could really be understood by the woman as implying that he is envisaging the invitation as one for a date (hence the humour of the exchange). While George's invitation could be understood as one to go on a date, attributing this interpretation to George's question remains in the hands of the woman in question, as "or something" only very broadly constrains the hearer's interpretation. This means that George could not necessary be held as accountable for this particular interpretation as he might be (hence the utility of not-saying). This implication should thus be analysed, it is suggested here, as arising through speaker not-saying rather than implicating (cf. example 6).

There are two main types of not-saying. The first is where the speaker and/or hearer treats unsaid content as knowable to both the speaker and hearer (or recipients more generally), but the speaker is taken to be less accountable for what is interpreted as meant by the speaker than had he been taken as implying that (as also seen in example 9 above). In the following exchange, Ned offers two distinct responses to Michael's declaratively formatted utterance. ${ }^{4}$

(10) (Michael and Ned have been discussing with two others who uses the instant coffee that is available in the staff tea room. Michael looks at Ned's coffee)

$1 \quad$ Michael: $\quad$ So you drink instant coffee.

\footnotetext{
${ }^{4}$ This exchange and subsequent discussion of it was noted down by the author at the time it occurred.
} 


$\begin{array}{lll}2 & \text { Ned: } & \begin{array}{l}((\text { pause })) \\ \text { I see. You're looking down on my choice of coffee. } \\ ((\text { laughter })\end{array} \\ \text { No, I bring my own coffee in. }\end{array}$

Ned's initial response in turn 2 to Michael's utterance identifies a particular implication as arising from what Michael has said, namely, a negative assessment of his choice of coffee. However, his subsequent response in turn 3 treats it as a polar (i.e. yes/no) interrogative that is seeking information through offering a candidate answer (Heritage and Raymond, 2012; Pomerantz, 1988; Raymond, 2003; Stivers, 2010). The issue here is whether Michael's utterance in turn 1 should be treated as a polar question seeking information (i.e. whether Ned normally drinks instant coffee as it appears he is doing at that time), or alternatively, as implying a negative assessment of Ned's choice of coffee (or even both). In view of the fact that Michael has previously claimed that he prefers coffee made through the expresso rather than the filter method, together with background knowledge about methods of coffee preparation and how they are generally evaluated in Australia and beyond (that is, expresso is seen as superior to filter which is preferred over instant), Ned (and the others present) could infer that Michael would not like to drink instant coffee himself, and furthermore that he might therefore look down on others who do drink instant coffee. The second inference constitutes a negative assessment of Ned's choice of coffee, and it is this understanding of the question that Ned displays in the subsequent turn after a slight pause. However, in the following turn, Ned follows up by distancing himself from his previous understanding, by treating Michael's initial utterance in turn 1 as a polar question. Ned later claimed that his interpretation of Michael's question as giving rise to a negative assessment was only something that could be attributed to Michael, it was not something that he necessarily really did attribute as an implication of the utterance. This possibility is also arguably indicated through the laughter on the part of other participants who were present at the time, which was occasioned by Ned essentially "catching out" Michael in meaning something they did not necessarily attribute as an implication of the utterance either. Michael also claimed that he did not intend (at least consciously) to imply this, although he readily acknowledged it could have been interpreted in this way. As both Michael and Ned treat this implication as attributable to, but not actually attributed to Michael as his intended meaning, it does not count as an implicature for which he can be held fully accountable. It is nevertheless treated by both as an implication arising from what Michael has said, and so he still bears some degree of responsibility for it. In this case, then, we arguably have an instance of speaker meaning where the interpretation of what is implied by an utterance (not the speaker) is left partly open to the recipient, thereby reducing Michael's degree of accountability for it.

The second type of not-saying is where the speaker treats the unsaid content as knowable to the recipient, and thus the speaker is held to be less accountable for what is interpreted as meant by the speaker than had he been taken as implying or saying that. In the following excerpt, for instance, the speaker's trailing-off conjunction (cf. Walker, 2012) can be understood in two ways by the recipient.

(11) ERCH: 11:07 (Chris and Emma have been talking about Emma's acupuncture business)

1 C: $\quad$ how do you go generally with most of your

2 customers ${ }^{\circ}$ are they happy o: ${ }^{\circ}$

$3 \quad(0.8)$ 
$4 \quad$ E: $\uparrow$ YEAH

(Haugh, 2011: 207)

Emma could understand Chris's utterance as either a polar question (i.e. "are they happy or not?") or as an alternative questions (e.g. "are they happy or generally satisfied"). It is thus left up to Emma to choose. Notably, while in many instances trailing-off disjunctives appear to be interpreted as polar questions, they are not always interpreted in this way (Haugh, 2011), so the choice is a real one for Emma. Chris increases the epistemic cline between himself and Emma (Heritage, 2009, 2012a, 2012b; Heritage and Raymond, 2012) by implicitly claiming that he is unable or unwilling to even guess the reactions of her customers by offering an "incomplete" candidate answer (Pomerantz, 1988). In that sense, accountability for meaning the customers might be "not happy", or other alternative possibilities, rests to some degree on Emma and how she responds to Chris's talk, as well as Chris himself. The upshot of this is that Chris is able to decrease his degree of accountability for what is taken to be meant here, which, incidentally, also invokes relational aspects of the epistemic order (Haugh, 2011; Heritage and Raymond, 2005; Raymond and Heritage, 2006)..$^{5}$

In summary, then, through formulating talk such that the speaker meanings arise through not-saying rather than saying or implying, speakers are able to modulate their degree of accountability for those meanings. In the case of not-saying this decrease in accountability arises through the speaker invoking particular aspects of the epistemic order, which, in turn, constitutes part of the broader moral order. We can also see from such examples how this moral order confers a certain degree of real-world consequentiality on such meanings, thereby underscoring once again the fundamentally deontological nature of speaker meaning.

\section{Concluding remarks}

The received view of speaker meaning is that it involves recognition of a specific kind of speaker intention by hearers, and that utterances are processed by users accordingly. The focus in analysing speaker meaning is thus generally on the speaker's commitment to the truth of information (although cf. Wilson and Sperber, 1993), and on (presumed) cognitive state-processes. The proposal in this paper for treating speaker meaning as a deontic concept offers an alternative view to this in two ways. First, what a speaker is held accountable for goes beyond the veracity of information to include other moral concerns, such as social rights, obligations, responsibilities and the like. Second, to be held interactionally accountable differs from inferring commitment. The former is tied to an understanding of speaker meaning as arising through incremental, sequentially-grounded discourse processing (e.g. Arundale, 2008, 2010; Gregoromichelaki and Kempson, forthcoming; Gregoromichelaki et al., 2011), while the latter is tied to a punctuated view of speaker meaning that arises at the level of utterance processing. Weigand (2009: 30) proposes that a discourse-processing view of meaning as something we are incrementally "coming to" (termed verstädigung in German) contrasts with an utterance-processing view of meaning as something we "reach" or "come to" (verstehen) (see also Kecskes, 2012). Of course

\footnotetext{
${ }^{5}$ Haugh (2011) suggests that in postulating a more equivocal candidate answer, Chris is able to decrease the risk of eliciting a disaffiliative response (Steensig and Drew, 2008). Chris is also able to display concern for the epistemic territory of Emma, which is interpretable as an indexing a polite stance or attitude.
} 
the former does not necessarily preclude an utterance-processing view, but there remains, nevertheless, the puzzle of how, if ever, to reconcile a discourse-processing view of speaker meaning as fundamentally deontological with a punctuated, utterance-processing view of speaker meaning as hearer's inferring speaker commitment to the veracity of reflexively intended mental representations. The first step in attempting to do so is to recognise that these constitute different perspectives. Thus, while a deontological notion of speaker meaning may seem of limited value to those focusing on speaker meaning at the level of utterance processing (cf. Wilson and Sperber, 2002: 627), participants do evidently orient to the deontological aspects of speaker meaning through holding speakers accountable to the moral order for such meanings in interaction. To dismiss such concerns is to ignore the very real-world consequentiality of what we are taken to mean.

There remains much to do, however, in furthering the proposals in this paper about speaker meaning as deontological. More work needs to be undertaken to explore the ways in which accountability can be modulated, as well as to further develop our understanding of the constituents of the moral order. The extent to which speakers can be held accountable for meanings is arguably an empirical question that will benefit from close, systematic examination of how speaker meanings emerge in real interaction through various kinds of meaning-actions. In this way, we may open the field up to potentially productive ways of furthering our understanding of the concept of speaker meaning, and the broader concept of pragmatic meaning of which speaker meaning constitutes just one type.

\section{References}

Arundale, Robert, 2008. Against (Gricean) intentions at the heart of human interaction. Intercultural Pragmatics 5(2). 231-260.

Arundale, Robert, 2010. Constituting face in conversation: face, facework and interactional achievement. Journal of Pragmatics 42(8). 2078-2105.

Austin, John L., 1962. How to Do Things with Words. Oxford, Clarendon Press.

Bach, Kent, Harnish, Robert, 1979. Linguistic Communication and Speech Acts. Cambridge, MA, MIT Press.

Bach, Kent, 2012. Saying, meaning, and implicating. In: Allan, Keith, Jaszczolt, Kasia (Eds.), The Cambridge Handbook of Pragmatics. Cambridge, Cambridge University Press, pp 47-67.

Bara, Bruno, 2010. Cognitive Pragmatics. Cambridge, MA, MIT Press.

Bara, Bruno, 2011. Cognitive pragmatics: the mental processes of communication. Intercultural Pragmatics 8(4). 443-485.

Bertuccelli Papi, Marcella, 1996. Insinuating: the seduction of unsaying. Pragmatics 6. 191-204.

Bilmes, Jack, 2009. Taxonomies are for talking: reanalyzing a Sacks classic. Journal of Pragmatics 41. 1600-1610.

Brandom, Robert, 1994. Making it Explicit. Reasoning, Representing and Discursive Commitment. Cambridge, MA, Harvard University Press.

Carassa, Antonella, Colombetti, Marco, 2009. Joint meaning. Journal of Pragmatics 41. 1837-1854.

Carassa, Antonella, Colombetti, Marco, 2011. Layers of joint commitments in interpersonal communication. In: Carlson, Laura, Hoselscher, Christoph, Shipley, Thomas (Eds.), Expanding the Space of Cognitive Science. 
Proceedings of the 33rd Annual Meeting of the Cognitive Science Society (CogSci2011). Boston, Cognitive Science Society, pp. 1055-1060.

Carston, Robyn, 2002. Thoughts and Utterances. The Pragmatics of Explicit

Communication. Oxford, Blackwell.

Cavell, Stanley, 1958. Must we mean what we say? Inquiry 1(1/4). 172-212.

Clark, Herbert, 1997. Dogmas of understanding. Discourse Processes 23. 567-598.

Clark, Herbert, 1996. Using Language. Cambridge, Cambridge University Press.

De Brabanter, Philippe, Dendale, Patrick, 2008. Commitment: the term and the notions. Belgian Journal of Linguistics 22. 1-14.

Deppermann, Arnulf, 2011. The study of formulations as a key to an interactional semantics. Human Studies 34. 115-128.

Garfinkel, Harold, 1964. Studies of the routine grounds of everyday activities. Social Problems 11. 225-250.

Garfinkel, Harold, 1967. Studies in Ethnomethodology. Englewood Cliffs, NJ, Prentice-Hall.

Garfinkel, Harold, Sacks, Harvey, [1970]1986. On formal structures of practical actions. In: Garfinkel, Harold (Ed.), Ethnomethodological Studies of Work. London, Routledge, pp. 157-190.

Gilbert, Margaret, 2000. Sociality and Responsibility: New Essays in Plural Subject Theory. Lanham, MD, Rowman \& Littlefield.

Gregoromickelaki, Eleni, Kempson, Ruth, forthcoming. Grammars as processes for interactive language use: incrementality and the emergence of joint intentionality. In: Capone, Alessandro, Lo Piparo, Franco, Carapezza, Marco (Eds.), Perspectives on Pragmatics and Philosophy. New York, Springer.

Gregoromichelaki, Eleni, Kempson, Ruth, Purver, Matthew, Mills, Gregory, Cann, Ronnie, Meyer-Viol, Wilfried, Healey, Patrick, 2011. Incrementality and intention-recognition in utterance processing. Dialogue and Discourse 2(1). 199-233.

Grice, Paul, 1957. Meaning. Philosophical Review 66:377-388.

Grice, Paul, 1967. William James Lectures.

Grice, Paul, 1975. Logic and conversation. In: Cole, Peter, Morgan, Jerry (Eds.), Syntax and Semantics, Volume 3. Speech Acts. New York, Academic Press, pp. 41-58.

Grice, Paul, 1989. Studies in the Way of Words. Cambridge, MA, Harvard University Press.

Harnish, Robert, M., 2005. Commitments and speech acts. Philosphica 75. 11-41.

Haugh, Michael, 2008. Intention and diverging interpretings of implicature in the "uncovered meat" sermon. Intercultural Pragmatics 5(2). 201-228.

Haugh, Michael, 2009. Face and interaction. In: Bargiela-Chiappini, Francesca, Haugh, Michael (Eds.), Face, Communication and Social Interaction. London, Equinox, pp. 1-30.

Haugh, Michael, 2010. Co-constructing what is said in interaction. In: Németh T., Enikö, Bibok, Károly (Eds.), The Role of Data at the Semantics-Pragmatics Interface. Berlin, Mouton de Gruyter, pp. 349-380.

Haugh, Michael, 2011. Practices and defaults in interpreting disjunction. In: Jaszczolt, Kasia, Allan, Keith (Eds.), Salience and Defaults in Utterance Processing. Berlin, Mouton de Gruyter, pp. 193-230.

Haugh, Michael, 2012. On understandings of intention: a response to Wedgwood. Intercultural Pragmatics 9:161-194. 
Haugh, Michael, forthcoming. Implicature, inference and cancellability. In: Capone, Alessandro, Lo Piparo, Franco, Carapezza, Marco (Eds.), Perspectives on Pragmatics and Philosophy. New York, Springer.

Haugh, Michael, Jaszczolt, Kasia M., 2012. Speaker intentions and intentionality. In: Allan, Keith, Jaszczolt, Kasia M. (Eds.), The Cambridge Handbook of Pragmatics. Cambridge, Cambridge University Press, pp. 87-112.

Heritage, John, 1984. Garfinkel and Ethnomethodology. Cambridge, Polity Press. Heritage, John, 1988. Explanations as accounts: a conversation analytic perspective. In: Antaki, Charles (Ed.), Analysing Everyday Explanation: A Casebook of Methods. London, Sage, pp. 127-144.

Heritage, John. 2009. Conversation analysis as social theory. In: Turner, Bryan (Ed.), New Blackwell Companion to Social Theory. Hoboken, NJ, Wiley-Blackwell, pp. 300-318.

Heritage, John. 2012a. Epistemics in action: action formation and territories of knowledge. Research on Language and Social Interaction 45(1). 1-29.

Heritage, John. 2012b. The epistemic engine: sequence organization and territories of knowledge. Research on Language and Social Interaction 45(1). 30-52.

Heritage, John, Raymond, Geoffrey, 2005. The terms of agreement: indexing epistemic authority and subordination in talk-in-interaction. Social Psychology Quarterly 68. 15-38.

Heritage, John, Raymond, Geoffrey, 2012. Navigating epistemic landscapes: acquiescence, agency and resistance in responses to polar questions. In: de Ruiter, J. P. (Ed.), Questions: Formal, Functional and Interactional Perspectives. Cambridge, Cambridge University Press, pp. 179-192.

Horn, Laurence, 2012. Implying and inferring. In: Allan, Keith, Jaszczolt, Kasia (Eds.), The Cambridge Handbook of Pragmatics. Cambridge, Cambridge University Press, pp. 69-86.

Jaszczolt, Kasia. M., 1999. Discourse, Beliefs and Intentions. Amsterdam, Elsevier. Jefferson, Gail. 2004. Glossary of transcript symbols with an introduction. In: Lerner, Gene (Ed.), Conversation Analysis: Studies from the First Generation. Amsterdam, John Benjamins, pp. 13-23.

Kecskes, Istvan, 2012. Is there anyone out there who really is interested in the speaker? Language and Dialogue 2(2). 285-299.

Lawrence, Samuel G., 2003. Rejecting illegitimate understandings. In: Glenn, Phillip, LeBaron, Curtis, Mandelbaum, Jenny (Eds.), Studies in Language and Social Interaction. Mahwah, NJ, Lawrence Erlbaum, pp. 195-205.

Levinson, Stephen, 2006. Cognition at the heart of human interaction. Discourse Studies 8(1). 85-93.

Mey, Jacob, 2001. Pragmatics. An Introduction ( $2^{\text {nd }}$ edn). Oxford, Blackwell.

Morency, Patrick, Oswald, Steve, de Saussure, Louis, 2008. Explicitness, implicitness and commitment attribution: a cognitive pragmatic perspective. Belgian Journal of Linguistics 22. 197-219.

Parret, Herman, 1994. Indirection, manipulation and seduction in discourse. In: Parret, Herman (Ed.), Pretending to Communicate. Berlin, Mouton de Gruyter, pp. 223-238.

Pomerantz, Anita, 1988. Offering a candidate answer: an information seeking strategy. Communication Monographs 55. 360-373.

Rancière, Jacques, 1999. Disagreement. Minneapolis, University of Minnesota Press. Raymond, Geoffrey, 2003. Grammar and social organization: yes/no interrogatives and the structure of responding. American Sociological Review 68. 939-967. 
Raymond, Geoffrey, Heritage, John, 2006. The epistemics of social relations: owning grandchildren. Language in Society 35. 677-705.

Sacks, Harvey. [1964]1992. Lectures on Conversation. Volume 1. Oxford, Blackwell.

Sanders, Robert, this issue. The discursive and social basis of speaker meaning: what makes self-repair, deception and sarcasm possible, and personal style useful. Journal of Pragmatics.

Saul, Jennifer, 2002. Speaker meaning, what is said, and what is implicated. Nous 36. 228-248.

Schegloff, Emanuel, 1997. Practices and actions: boundary cases of other-inititated repair. Discourse Processes 23. 599-545.

Schegloff, Emanuel, 2000. When 'others' initiate repair. Applied Linguistics 21. 205243.

Schegloff, Emanuel, Jefferson, Gail, Sacks, Harvey, 1977. The preference for selfcorrection in the organization of repair in conversation. Language 53. 361-382.

Searle, John, 1969. Speech Acts. Cambridge, Cambridge University Press.

Searle, John, 1979. Expression and Meaning. Studies in the Theory of Speech Acts. Cambridge, Cambridge University Press.

Searle, John, 2007. What is language: some preliminary remarks. In: Kecskes, Istvan, Horn, Laurence (Eds.), Explorations in Pragmatics. Linguistic, Cognitive and Intercultural Aspects. Berlin, Mouton de Gruyter, pp. 7-37.

Searle, John. 2010. Making the Social World. Oxford, Oxford University Press.

Sidnell, Jack, 2012. Declaratives, questioning, defeasibility. Research on Language and Social Interaction 45(1). 53-60.

Sperber, Dan, Wilson, Deirdre, 1995. Relevance. Communication and Cognition $\left(2^{\text {nd }}\right.$ edn). Oxford, Blackwell.

Sperber, Dan, Wilson, Deirdre, 2008. A deflationary account of metaphors. In: Gibbs, Raymond (Ed.), The Cambridge Handbook of Metaphor and Thought. Cambridge, Cambridge University Press, pp. 84-105.

Sperber, Dan, Clement, Fabrice, Heintz, Christophe, Mascaro, Olivier, Mercier, Hugo, Origgi, Gloria, Wilson, Deirdre, 2010. Epistemic vigilence. Mind and Language 25. 359-393.

Steensig, Jakob, Drew, Paul, 2008. Introduction: questioning and affiliation/disaffiliation in interaction. Discourse Studies 10. 5-15.

Stivers, Tanya, 2010. An overview of the question-response system in American English conversation. Journal of Pragmatics 42. 2772-2781.

Stivers, Tanya, Mondada, Lorenza, Steensig, Jakob, 2011. Knowledge, morality and affiliation in social interaction. In: Stivers, Tanya, Mondada, Lorenza, Steensig, Jakob (Eds.), The Morality of Knowledge in Conversation. Cambridge, Cambridge University Press, pp. 3-24.

Walker, Gareth, 2012. Coordination and interpretation of vocal and visible resources: 'trail-off' conjunctions. Language and Speech 55. 141-163.

Walker, Traci, Drew, Paul, Local, John, 2011. Responding indirectly. Journal of Pragmatics 43. 2434-2451.

Wedgwood, Daniel, 2011. The individual in interaction: why cognitive and discourselevel pragmatics need not conflict. Intercultural Pragmatics 8(4). 517-542.

Weigand, Edda, 2009. The dialogic principle revisited. Speech acts and mental states. In: Weiglund, Edda (Ed.), Language as Dialogue. Amsterdam, John Benjamins, pp. 21-44.

Weizman, Elda, 1985. Towards an analysis of opaque utterances: hints as a request strategy. Theoretical Linguistics 12. 153-163. 
Wilson, Deirdre, Sperber, Dan, 1993. Linguistic form and relevance. Lingua 90. 1-25.

Wilson, Deirdre, Sperber, Dan, 2002. Truthfulness and relevance. Mind 111. 583-632.

Wilson, Deirdre, Sperber, Dan. 2006. The pragmatics of verbal irony: echo or pretence? Lingua 116. 1722-1743.

Wilson, Deirdre, Sperber, Dan, 2012. Meaning and Relevance. Cambridge, Cambridge University Press.

\section{Appendix: Transcription conventions (following Jefferson 2004)}

$\begin{array}{ll}{[\quad]} & \text { overlapping speech } \\ (0.5) & \text { numbers in brackets indicate pause length } \\ (.) & \text { micropause } \\ : & \text { elongation of vowel or consonant sound } \\ - & \text { word cut-off } \\ & \text { falling or final intonation } \\ ? & \text { rising intonation } \\ i & \text { falling then rising intonation } \\ , & \text { 'continuing' intonation } \\ = & \text { latched utterances } \\ \text { underlining } & \text { contrastive stress or emphasis } \\ \text { CAPS } & \text { markedly louder } \\ \circ \circ & \text { markedly soft } \\ \text { Hhh } & \text { in-breathing } \\ \downarrow \uparrow & \text { sharp falling/rising intonation } \\ \star \star & \text { hearably smiling voice } \\ >< & \text { talk is compressed or rushed } \\ <> & \text { talk is markedly slowed or drawn out } \\ (\quad) & \text { blank space in parentheses indicates uncertainty about the transcription }\end{array}$

